\title{
Effect of microwave sintering temperature on structure and properties of bioceramics based on biogenic hydroxyapatite
}

\author{
H.Tovstonoh $^{* * * *}$, O.Sych ${ }^{* *}$, V.Skorokhod ${ }^{* *}$ \\ "National Technical University of Ukraine "Kyiv Polytechnical Institute", \\ 37 Peremogy Ave., 03056 Kyiv, Ukraine \\ :*: I.Frantsevich Institute for Problems of Materials Science, National \\ Academy of Sciences of Ukraine, 3 Krzhyzhanovsky Str., 03680 Kyiv, \\ Ukraine
}

Received June 10, 2014

\begin{abstract}
The present work demonstrates the possibility to produce medicine-aimed ceramics on the basis of biogenic hydroxyapatite with structural-mechanical properties required for replacement of the bone tissue defects using techniques of microwave sintering at 800$1100^{\circ} \mathrm{C}$. It has been established that porosity of the bioceramics obtained in the temperature range of $800-1000^{\circ} \mathrm{C}$ ( 5 min exposure to the maximal temperature) equals about $40 \%$, whereas at $1100^{\circ} \mathrm{C}$ it decreases down to $37 \%$. Compression strength increases with increasing the temperature from 25 to $38 \mathrm{MPa}$.
\end{abstract}

Показана возможность получения керамики медицинского назначения на основе биогенного гидроксиапатита методом микроволнового спекания при $800-1100^{\circ} \mathrm{C}$ с достаточными структурно-механическими свойствами для замещения дефектов костной ткани. Установлено, что пористость биокерамики, полученной в интервале температур 800-1000 ${ }^{\circ} \mathrm{C}$ (выдержка при максимальной температуре 5 мин.), составляет $40 \%$, а при $1100^{\circ} \mathrm{C}$ - уменьшается до $37 \%$. Прочность на сжатие возрастает от 25 до 38 МПа с повышением температуры и близка к прочности губчатой кости человека.

Вплив температури мікрохвильового спікання на структурно-механічні властивості біокераміки на основі біогенного гідроксиапатиту. Г.Б.Товстоног, О.Є.Сนч, B.В.Скороход.

Показана можливість отримання кераміки медичного призначення на основі біогенного гідроксиапатиту методом мікрохвильового спікання при $800-1100^{\circ} \mathrm{C}$ з достатніми структурно-механічними властивостями для заміщення дефектів кісткової тканини. Встановлено, що пористість біокераміки, отриманої в інтервалі температур $800-1000^{\circ} \mathrm{C}$ (витримка при максимальній температурі 5 хв.), становить $\sim 40 \%$, а при $1100^{\circ} \mathrm{C}-$ зменшується до $37 \%$. Міцність на стиск зростає від 25 до 38 МПа з підвищенням температури і є близькою до міцності губчатої кістки людини.

\section{Introduction}

Problems associated with treatment of traumas of different origin, including replacement of bone tissue defects, become more and more urgent in the whole world as well as in Ukraine. Injured patients require a long-time treatment, which is not always efficient, and thus such traumas often cause their primary disablement. Therefore development of novel implant materials alongside with improvement of the available ones is one the primary tasks for the up to date material science.

Among a wide variety of materials used in practical medicine for bone defect re- 
placement such as metals, ceramics, polymers and composites, bioactive materials on the basis of hydroxyapatite (HA) are the most promising and popular. $\mathrm{HA}$ is a material with the closest to natural bone composition and so it is the most acceptable for implants manufacture $[1,2]$. There are two main types of HA: i) synthetic HA obtained by techniques of solid state synthesis, deposition, or sol-gel procedure et al. [3] and ii) biogenic HA (BHA), which is traditionally obtained from bones of cattle [4-6]. Thanks to the same chemical composition and structure (as those of the natural bone) combined with the low cost, production of the latter is promising. In addition, there has been reported that $\mathrm{BHA}$ better promote processes of bone tissue regeneration [4, 7].

Articles from HA-based ceramics are fabricated by traditional methods of powder metallurgy such as hot pressing, doubling of polymer matrix structure, freeze casting and spark plasma sintering [8, 9].

Usage of microwave sintering as an efficient technique for fabrication of medicineaimed articles with high strength and required porosity is one of the most promising methods. However, by now there has not yet been enough information on peculiarities of sintering and formation of the BHA based bioceramics via microwave sintering.
Hence the aim of the present work was to investigate the peculiarities of microwave sintering of BHA, in particular the effect of temperature on the structure and properties of the BHA ceramics.

\section{Materials and procedures}

As a starting material, BHA of the trade mark "Osteopatyt Keramichnyi" with particles size to $160 \mu \mathrm{m}$ was chosen. Cylindershaped samples were made by double-action compacting under pressure of $200 \mathrm{MPa}$ followed by sintering in a high temperature microwave muffle oven $(1.5 \mathrm{~kW} ; 2.45 \mathrm{GHz})$ at temperatures $800,900,1000$ and $1100^{\circ} \mathrm{C}$ with 5 min exposure to the maximal sintering temperature.

Structure of the samples was examined by means of raster electron microscopy using a REM-106I (VAT "SELMI", Ukraine) microscope. Special program SIAMS Photolab (TOV "SIAMS", Russia) for analysis of images and modeling of the structures was applied to characterize the grains and pores sizes distributions. Phase composition was determined using a XRD difractometer Ultima IV (Rigaku, Japan). Chemical composition was examined by energy-dispersive X-ray fluorescent element analysis employing an analyzer Expert 3L (InAM, Ukraine). Com-
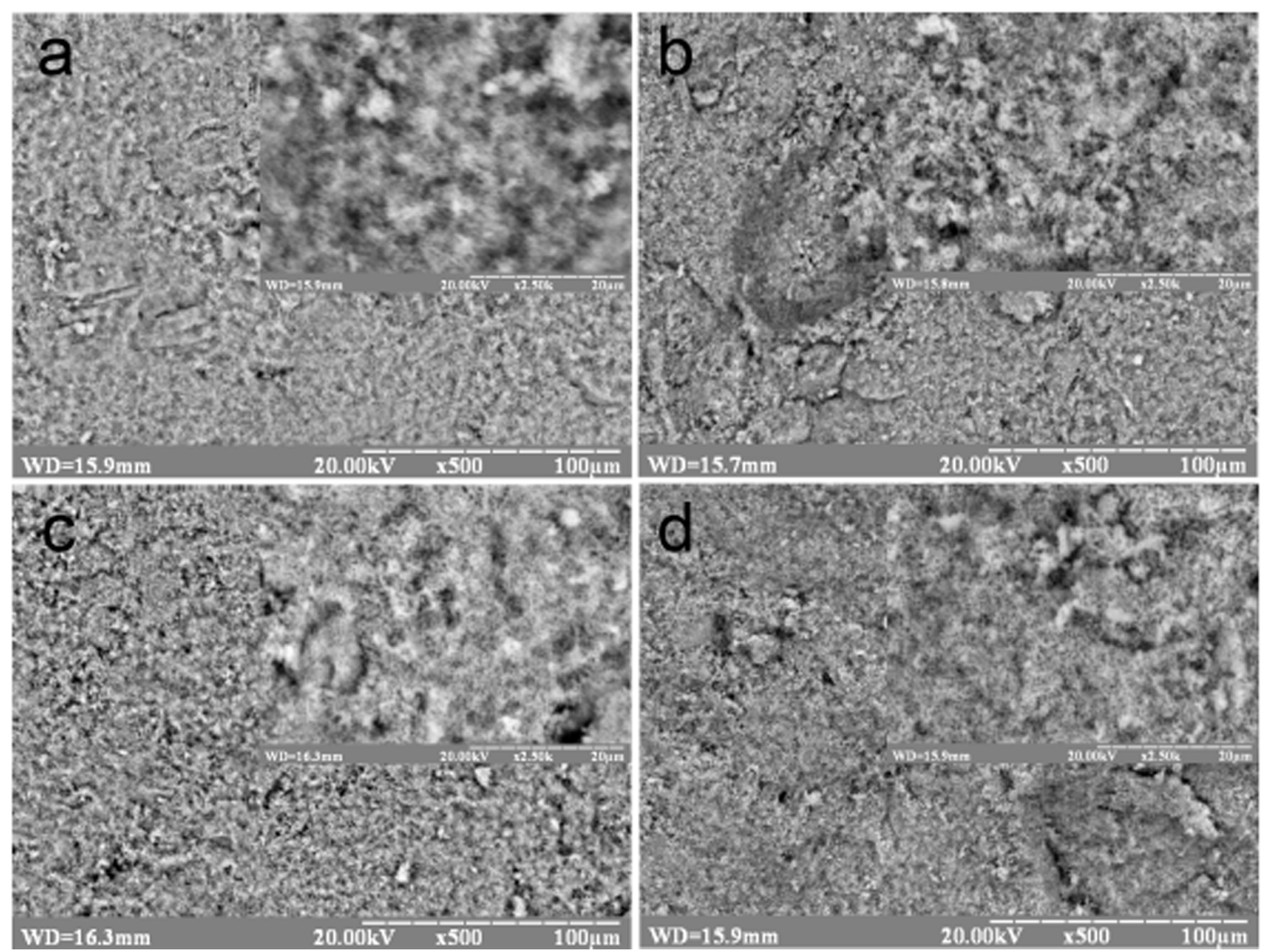

Fig. 1. Microstructure of BHA samples obtained via microwave sintering at different temperatures $\left({ }^{\circ} \mathrm{C}\right):$ (a) 800, (b) 900, (c) 1000, (d) 1100. 

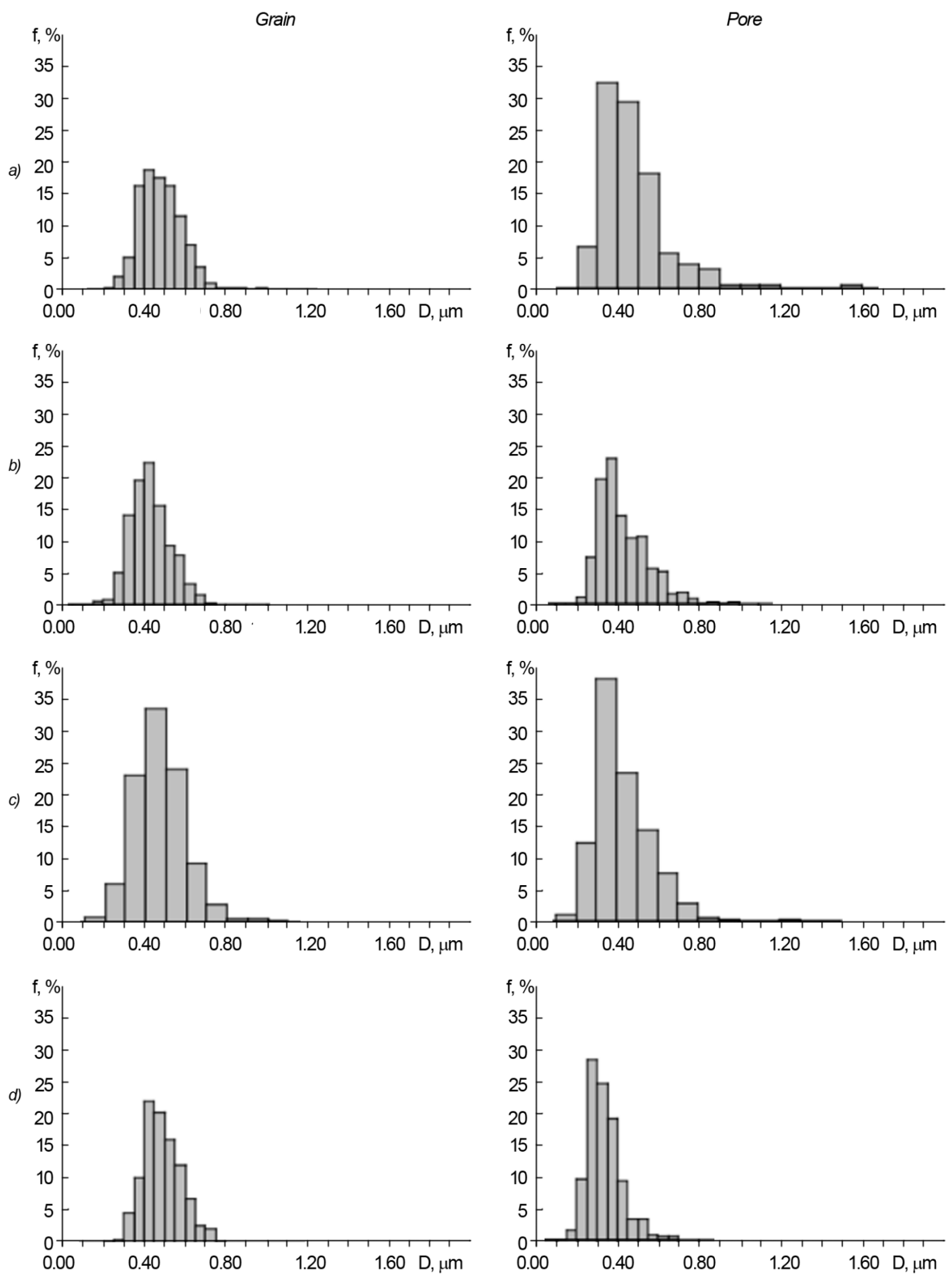

Fig. 2. Grains and pores size distribution in BHA samples obtained via microwave sintering at different temperatures $\left({ }^{\circ} \mathrm{C}\right):$ (a) 800, (b) 900, (c) 1000, (d) 1100.

pression strength was determined with the aid of a test apparatus of the Ceram test system.

Besides, we measured porosity, volume shrinkage and sintering-caused mass loss by the traditional techniques.
To evaluate biological activity of the materials obtained, special experiments in vitro were conducted, in particular on determination of the sample solubility in the physiological solution $(0.9 \% \mathrm{NaCl}$ water solution) using techniques for determination of the mass loss during exposure of the 


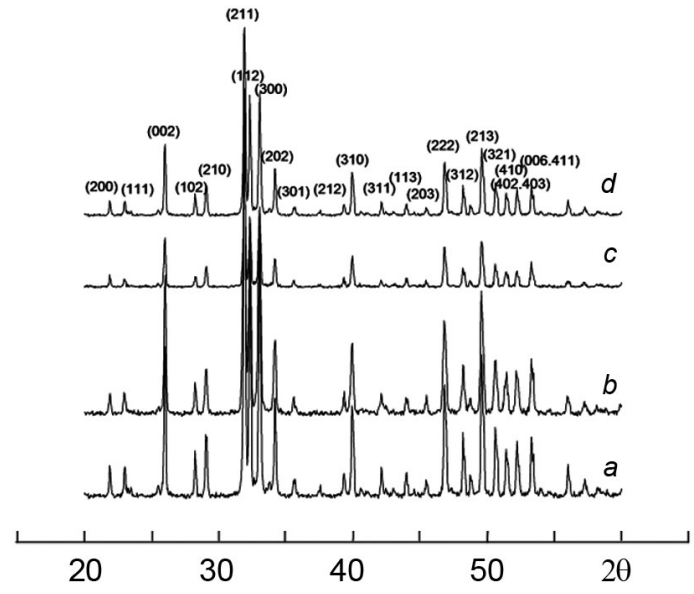

Fig. 3. XRD patterns from BHA samples obtained via microwave sintering at different temperatures $\left({ }^{\circ} \mathrm{C}\right):$ (a) 800 , (b) 900 , (c) 1000, (d) 1100 .

samples to the action of model media for some period of time ( 2 days in our case) at $36-37^{\circ} \mathrm{C}[10]$.

\section{Results and discussion}

Fig. 1 demonstrates the structure of the BHA samples fabricated at different sintering temperatures. As can be seen, with increasing the sintering temperature the structure of material becomes more uniform with uniform pore distribution; herein the minimal and average grain sizes increase from 0.1 to $0.2 \mu \mathrm{m}$ and from 0.45 to $0.8 \mu \mathrm{m}$, respectively (Fig. 2). The minimal pore size also increases from 0.04 to $0.2 \mu \mathrm{m}$ with increasing the temperature from 800 to $1100^{\circ} \mathrm{C}$. However, the average pore size does not depend on temperature and is equal to about $0.5 \mu \mathrm{m}$. The increase in the pores and grains sizes may be related to the processes of surface and volume diffusion leading to grains and pores aggregation at the expense of the smaller ones, which is more thermodinamically preferable. Moreover, it was established that predominant quantity of the grains and pores falls into diapason of $0.2-0.8 \mu \mathrm{m}$ independently of the sintering temperature.

The XRD analysis revealed that with temperature increasing the phase composition of the samples remains the same and the material is composed of the $\mathrm{HA}$ phase $\left(\mathrm{Ca}_{5}\left(\mathrm{PO}_{4}\right)_{3} \mathrm{OH}\right.$, Card \# 9-432) only (Fig. 3), which agrees well with the literature data on thermal stability of BHA up to $1350^{\circ} \mathrm{C}$ [11-13].

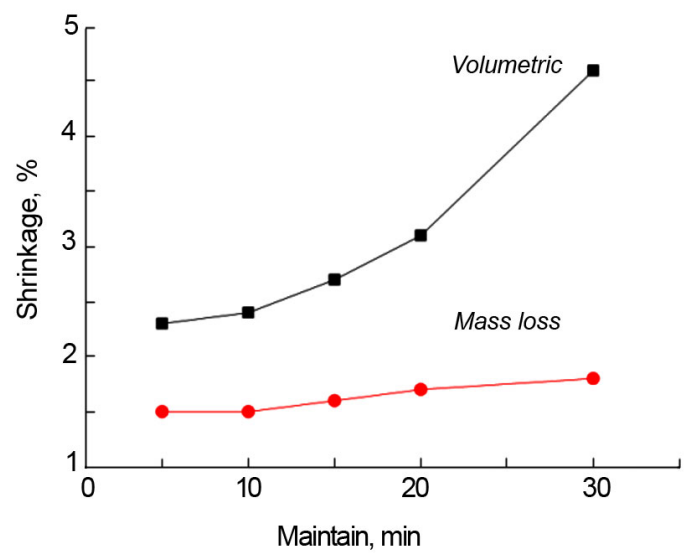

Fig. 4. The temperature effect on change in the lattice parameters of BHA samples under microwave sintering.

The chemical analysis confirmed stability of the sample composition as well: at all sintering temperatures the phase of stoichiometric HA remains. Besides, there is a small amount of $\mathrm{Cu}(0.010 \pm 0.001$ mass. \%), $\mathrm{Zn}(0.020 \pm 0.001$ mass. \%), and Fe (0.10.3 mass. \%) resulted from contamination during milling of the starting powder.

Fig. 4 represents changes in the volume shrinkage and mass loss under the sintering depending on temperature for the BHA samples. As can be seen, with increasing temperature the mass loss increases from 0.9 to $2.2 \%$ and the volume shrinkage increases from 0.1 to $7.5 \%$. This can be attributed to intensification of diffusion processes under the sintering temperature rise, which provides densification and strengthening of the material.

In the temperature range of $800-1000^{\circ} \mathrm{C}$, porosity of the samples practically does not depend on temperature and is equal to $40.0 \pm 0.5 \%$, but with the further temperature rise to $1100^{\circ} \mathrm{C}$ it decreases by $37 \%$ correlating with the change in volume shrinkage. Herein the open porosity is over $95 \%$ of the total porosity, which is one of the necessary demands for porous implants because the open porosity determines processes of penetration of biological fluids and accelerates regeneration of the bone tissue.

Compression strength of the obtained ceramics increases from 25 to $38 \mathrm{MPa}$ with increasing temperature. These values are close to the human spongy bone strength [14]. For comparison, traditional sintering at $1000^{\circ} \mathrm{C}$ (pressure of compaction $350 \mathrm{MPa}$ ) yields HA ceramics on the basis of enamel and dentin characterized by com- 
pression strength of 27 and $10 \mathrm{MPa}$, respectively [13].

The investigation of the BHA ceramics solubility in the physiological solution established that practically it does not depend on the sintering temperature and is equal to 0.17-0.19 mass. \% a day.

\section{Conclusions}

The work has demonstrated the possibility to fabricate medicine-aimed ceramics on the basis of BHA using microwave sintering in the temperature range of $800-1100^{\circ} \mathrm{C}$ with 5 min exposure to the maximal temperature. This method was shown to provide fabrication of the samples characterized by homogeneous fine-grained structure and uniform pores size distribution, porosity to $40 \%$ and compression strength up to $38 \mathrm{MPa}$ (which is close to the strength of the natural bones). Therefore the obtained material can be promising for replacement of the human bone tissue defects.

\section{References}

1. M.Aminzare, A.Eskandari, M.H.Baroonian et al., Ceram. Int., 39, 2197 (2013).

2. E.Champion, Acta Biomater., 9, 5855 (2013).

3. C.Guzm'an V'azquez, C.Pina Barba, N.Mungu'a, Revista Mexicana de f'isica, 51, 284 (2005).

4. A.Raksujarit, K.Pengpat, G.Rujijanagul, T.Tunkasiri, Mater. Des., 31, 1658 (2010).

5. Y.Gao, W.-L.Cao, X.-Y.Wang et al., J.Mater. Sci.:Mater.Med., 17, 815 (2006).

6. C.Y.Ooi, M.Hamdi, S.Ramesh, Ceram.Int., 33, 1171 (2007).

7. A.Ruksudjarit, K.Pengpat, G.Rujijanagul, T.Tunkasiri, Curr.Appl.Phys., 8, 270 (2008).

8. A.S.Fomin, S.M.Barinov, V.M.Ievlev et al., Dokl.Chem., 418, 22 (2008).

9. Y.Zhang, K.Zuo, Y.-P.Zeng, Ceram.Int., 35, 2151 (2009).

10. C.Drouet, F.Bosc, M.Banu et al., Powder. Technol., 190, 118 (2009).

11. O.Sych, N.Pinchuk, Proc.Appl.Ceram., 1, 1 (2007).

12. J.H.G.Rocha, A.F.Lemos, S.Agathopoulos et al., Bone, 37, 850 (2005).

13. F.N.Oktar, Ceram.Int., 33, 1309 (2007).

14. S.A.Goldstein, J.Biomech., 20, 1055 (1987). 